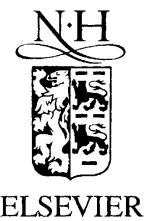

\title{
Infrared and Mössbauer studies of iron in aluminosilicate glasses
}

\author{
M.G. Ferreira da Silva ${ }^{a, *}$ B.F.O. Costa ${ }^{b}$ \\ a Departamento de Engenharia Cerâmica e do Vidro, UIMC, Universidade de Aveiro, 3810-193 Aveiro, Portugal \\ b Departamento de Física, Universidade de Coimbra, P3000 Coimbra, Portugal
}

\begin{abstract}
Samples of $10 \mathrm{Fe}_{2} \mathrm{O}_{3} \cdot 10 \mathrm{Al}_{2} \mathrm{O}_{3} \cdot 80 \mathrm{SiO}_{2}$ composition were prepared by the sol-gel method and heat-treated between 120 and $1300{ }^{\circ} \mathrm{C}$ under oxidising (air) conditions. These samples were studied by Fourier transformer infrared (FTIR) and Mössbauer spectroscopy. The results indicate that $\mathrm{Fe}^{3+}$ is in octahedral sites at $250{ }^{\circ} \mathrm{C}$ and in tetrahedral sites between 500 and $1300{ }^{\circ} \mathrm{C}$. Goethite and hematite particles are present in the 250 and $500{ }^{\circ} \mathrm{C}$ samples and hematite particles in the samples heat-treated between 1000 and $1300{ }^{\circ} \mathrm{C}$. The hematite particles, present in the samples, show a lower hyperfine field $(47.91 \pm 0.08 \mathrm{~T})$ than that usually seen for hematite $(51.5 \mathrm{~T})$. This is due to the fact of $\mathrm{Al}^{3+}$ ions take the place of $\mathrm{Fe}^{3+}$ ions in hematite particles. (C) 2001 Elsevier Science B.V. All rights reserved.
\end{abstract}

\section{Introduction}

In aluminosilicate glasses $\mathrm{Fe}^{3+}$ and $\mathrm{Al}^{3+}$ can occupy octahedral and/or tetrahedral sites. In silicate glasses $\mathrm{Fe}^{3+}$ ions are mainly in tetrahedral sites [1-5]. However, when the iron content is relatively high the iron tends to aggregate forming clusters [3]. Mössbauer and Fourier transformer infrared (FTIR) spectroscopies are good techniques for obtaining information about the structural behaviour of iron in glasses [6]. Mössbauer, data give information about the coordination (isomer shift), symmetry (quadrapole splitting), and content (relative area) of the iron in glasses [7].

Samples of the $10 \mathrm{Al}_{2} \mathrm{O}_{3}-10 \mathrm{SiO}_{2}-80 \mathrm{SiO}_{2}$ composition were already studied by X-ray diffraction (XRD), scanning electron microscopy (SEM),

\footnotetext{
${ }^{*}$ Corresponding author. Tel.: +351-234 370 354; fax: +351234425300 .

E-mail address: gsilva@cv.ua.pt (M.G. Ferreira da Silva).
}

electron spin resonance (ESR) and ac susceptibility measurements $[8,9]$. Nevertheless, some aspects of the iron incorporation, in these samples, has remained in doubt. This paper presents results of an investigation using infrared and Mössbauer spectroscopies, in order to detect new aspects of the iron oxide incorporation in gel-derived materials of $10 \mathrm{Al}_{2} \mathrm{O}_{3}-10 \mathrm{SiO}_{2}-80 \mathrm{SiO}_{2}$ composition.

\section{Experimental procedure}

Samples of $10 \mathrm{Fe}_{2} \mathrm{O}_{3} \cdot 10 \mathrm{Al}_{2} \mathrm{O}_{3} \cdot 80 \mathrm{SiO}_{2}$ composition $\left(\mathrm{mol}^{\%}\right)$ ) were prepared from tetraethylorthosilicate (TEOS), $\mathrm{Fe}\left(\mathrm{NO}_{3}\right)_{3} \cdot 9 \mathrm{H}_{2} \mathrm{O}$ and $\mathrm{Al}\left(\mathrm{NO}_{3}\right)_{3} \cdot 9 \mathrm{H}_{2} \mathrm{O}$, as sources of silica, iron and aluminium oxide. First, a mixture of TEOS, ethanol and water in a molar ratio 1:3:1 was stirred for one hour at room temperature. After this hydrolysis the two nitrates, which were dissolved in water, were added to give a $\mathrm{H}_{2} \mathrm{O} /$ TEOS ratio of 
20. This solution was stirred for one hour, poured into Petri dishes and allowed to gel and dried at 60 ${ }^{\circ} \mathrm{C}$. The gel obtained was heat-treated at $120{ }^{\circ} \mathrm{C}$ $(48 \mathrm{~h})$, at 250 and $500{ }^{\circ} \mathrm{C}(4 \mathrm{~h})$ and between 1000 and $1300{ }^{\circ} \mathrm{C}(2 \mathrm{~h})$ under oxidising (air) conditions.

The structure of the samples was examined using Mössbauer and infrared spectroscopies. Infrared transmission spectra were obtained by $\mathrm{KBr}$ method using a FTIR Mattson 7000 spectrometer. The Mössbauer absorbers were prepared by enclosing powdered samples into a plastic holder. ${ }^{57} \mathrm{Fe}$ Mössbauer spectra were registered at room temperature in a transmission geometry with a ${ }^{57} \mathrm{Co} / \mathrm{Rh}$ source of about $30 \mathrm{mCi}$. The velocity wave had a symmetrical 'sawtooth' shape and the spectrometer was calibrated against $\alpha$-Fe foil absorber. The evaluation of the spectra was done using a least-squares-minimum computer fit to a superposition of Lorentzian line shapes.

\section{Results}

\subsection{FTIR results}

The infrared absorption spectra of the $10 \mathrm{Fe}_{2} \mathrm{O}_{3} \cdot 10 \mathrm{Al}_{2} \mathrm{O}_{3} \cdot 80 \mathrm{SiO}_{2}$ sample (Fig. 1) show a band near $1650 \mathrm{~cm}^{-1}$ that is due to $\mathrm{H}_{2} \mathrm{O}$ presence [10]. This water disappears for heat-treatment temperature higher than $500{ }^{\circ} \mathrm{C}$. The broad absorption band at $3460 \mathrm{~cm}^{-1}$ can be assigned to both $\mathrm{OH}$ and $\mathrm{H}_{2} \mathrm{O}$ vibrations [10]. A peak at 1390 $\mathrm{cm}^{-1}$ is assigned to $\mathrm{C}-\mathrm{H}$ bending vibrations $[10,11]$. The intensity of this peak is considerably reduced for heat-treatment temperature higher than $120{ }^{\circ} \mathrm{C}$. The band at $1090 \mathrm{~cm}^{-1}$ due to the vibration of bridging oxygen present in $\mathrm{SiO}_{4}$ units [12-14] shifts to higher wave numbers with increasing treatment temperature (Fig. 1). A band attributed to the presence of defect bonds in a silicate network [13] is observed at $900 \mathrm{~cm}^{-1}$, in the spectra of the 1200 and $1300{ }^{\circ} \mathrm{C}$ samples (Fig. 1). The band around $800 \mathrm{~cm}^{-1}$ is characteristic of symmetric stretching vibrations of $\mathrm{SiO}_{4}$ units [15]. This band exhibits a shift toward lower wave number at 1200 and $1300{ }^{\circ} \mathrm{C}$. In the spectra of the samples heat-treated at 1000,1200 and $1300{ }^{\circ} \mathrm{C}$ a band near $600 \mathrm{~cm}^{-1}$ (Fig. 1) can be attributed to

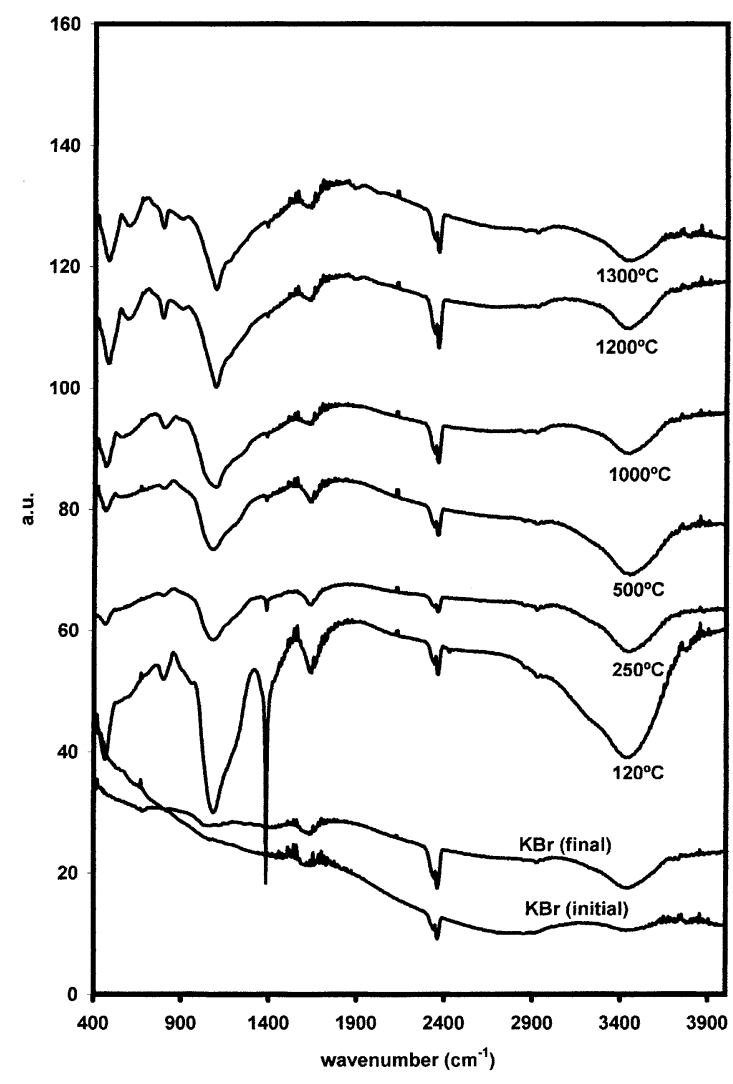

Fig. 1. FTIR spectra of the $10 \mathrm{Al}_{2} \mathrm{O}_{3} \cdot 10 \mathrm{Fe}_{2} \mathrm{O}_{3} \cdot 80 \mathrm{SiO}_{2}$ sample heat-treated between 120 and $1300{ }^{\circ} \mathrm{C}$ and $\mathrm{KBr}$ spectra (before (initial) and after (final) achieving iron spectra).

the vibrations of $\mathrm{FeO}_{4}$ [13], $\mathrm{AlO}_{4}$ or $\mathrm{AlO}_{6}$ [15] units. In all the samples a band near $470 \mathrm{~cm}^{-1}$ is present. This band is assigned to the vibration of $\mathrm{Si}-\mathrm{O}-\mathrm{Si}$ bonds [16-18] and $\mathrm{FeO}_{6}$ units [13] and shifts to higher wave number when the temperature increases (Fig. 1). Moreover, EPR results [9] show that $\mathrm{Fe}^{3+}$ ions are present in the samples.

\subsection{Mössbauer spectroscopy}

The Mössbauer results for the $10 \mathrm{Al}_{2} \mathrm{O}_{3}$. $10 \mathrm{Fe}_{2} \mathrm{O}_{3} \cdot \mathrm{SiO}_{2}$ sample heat-treated between 250 and $1300{ }^{\circ} \mathrm{C}$ are shown in Fig. 2 and Table 1. The room temperature Mössbauer spectra of the 250 ${ }^{\circ} \mathrm{C}$ sample show a ferric iron doublet and two sextets (Fig. 2(a)). The isomer shift of the doublet (IS $=0.36 \pm 0.01$, Table 1 ) is typical of the pres- 


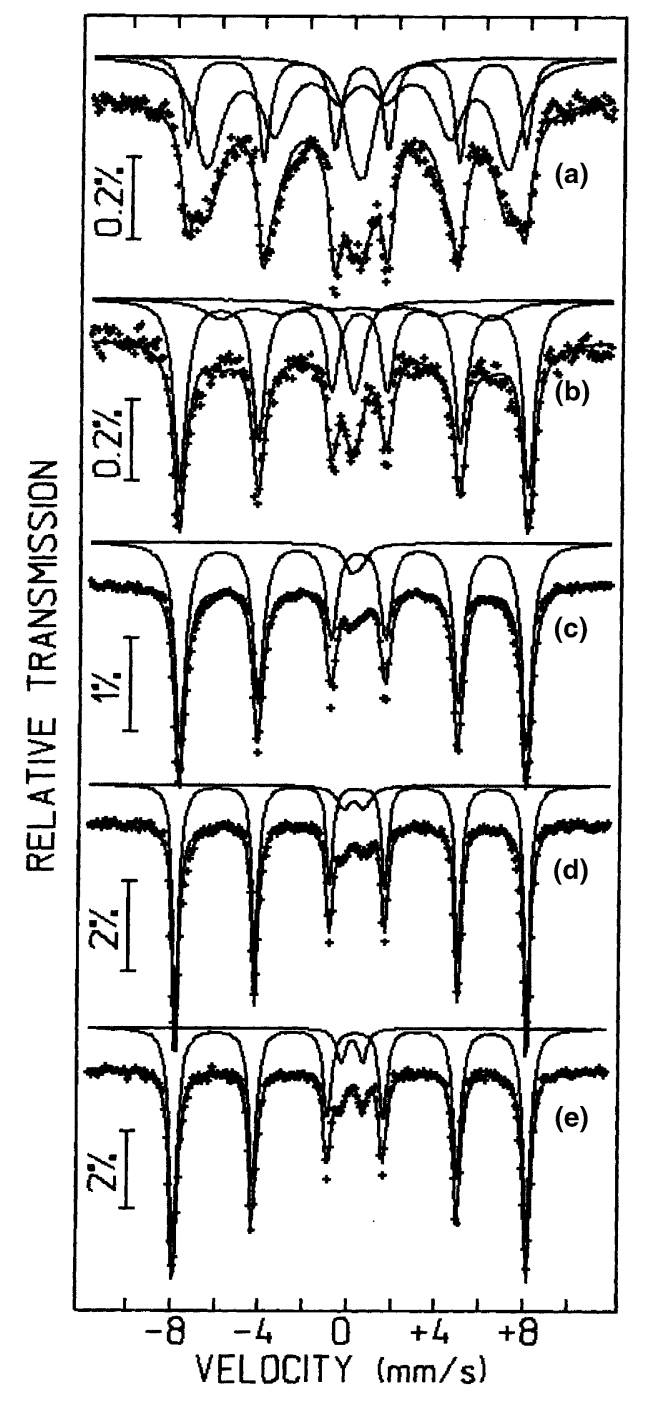

Fig. 2. Mössbauer spectra taken at $300 \mathrm{~K}$ of the $10 \mathrm{Al}_{2} \mathrm{O}_{3} \cdot 10 \mathrm{Fe}_{2} \mathrm{O}_{3} \cdot 80 \mathrm{SiO}_{2}$ sample heat-treated at: (a) $250{ }^{\circ} \mathrm{C}$; (b) $500{ }^{\circ} \mathrm{C}$; (c) $1000{ }^{\circ} \mathrm{C}$; (d) $1200{ }^{\circ} \mathrm{C}$ and (d) $1300{ }^{\circ} \mathrm{C}$.

ence of $\mathrm{Fe}^{3+}$ in octahedral sites [19]. The two sextet are related with the presence of goethite and hematite [20]. However, hematite has a low hyperfine field $(47.91 \pm 0.08 \mathrm{~T})$ than that foreseen for hematite $(51.5 \mathrm{~T})$ [20]. The shoulder observed in the $250{ }^{\circ} \mathrm{C}$ spectrum cannot be ascribed to a $\mathrm{Fe}^{2+}$ site because the introduction of $\mathrm{Fe}$ and $\mathrm{Al}$ as nitrates produces an efficient oxidation [21,22]. When the heat-treatment temperature increases Mössbauer spectra and parameters (Fig. 2(b)-(e), Table 1) show a modification in the $\mathrm{Fe}^{3+}$ coordination (tetrahedral sites) and the hyperfine field of hematite increases (Fig. 2 and Table 1). In the $500^{\circ} \mathrm{C}$ sample the isomer shift of $\mathrm{Fe}^{3+}$ (IS $=0.22 \pm 0.03-$ Table 1) is lower than the values obtained for the samples heat-treated between 1000 and $1300{ }^{\circ} \mathrm{C}$. The percentage of hematite is higher at $1000{ }^{\circ} \mathrm{C}$ than at 1200 or $1300{ }^{\circ} \mathrm{C}$. The central doublet in the Mössbauer spectra is the contribution from $\mathrm{Fe}^{3+}$ in the matrix. We have not assigned the central doublet to a supermagnetic behaviour because iron particles, as observed by SEM [8], are too large.

\section{Discussion}

The FTIR $1390 \mathrm{~cm}^{-1}$ peak (Fig. 1) has a low intensity at temperature higher than $120{ }^{\circ} \mathrm{C}$ because the residual alkoxy groups present in the sample are removed by oxidation $[10,11]$. The 1090 and $470 \mathrm{~cm}^{-1}$ bands shifts to larger wave numbers at higher temperature due to an increasing of the strength of $\mathrm{Si}-\mathrm{O}$ bonds with the progressive polycondensation of the gel-sample. The glass network formed by the sol-gel method is initially porous [23]. At 250 and $500{ }^{\circ} \mathrm{C}$ the samples are porous but, around $800{ }^{\circ} \mathrm{C}$, the porous network densifies and the pores, water and $\mathrm{OH}$ groups are eliminated (Fig. 1). Isomer shift data (Table 1) show that at $250{ }^{\circ} \mathrm{C}$ iron ions are in octahedral sites (IS $=0.36 \pm 0.01 \mathrm{~mm} / \mathrm{s} ; I(\%)=15.01)$. The octahedral symmetry of $\mathrm{Fe}^{3+}$ ions can be understood considering that, at $250{ }^{\circ} \mathrm{C}$, the network is porous and $\mathrm{Fe}^{3+}$ ions are in the pores as $\left[\mathrm{Fe}\left(\mathrm{H}_{2} \mathrm{O}\right)_{x}(\mathrm{OH})_{6-x}\right]^{3+}$ or/and $\left[\mathrm{Fe}\left(\mathrm{H}_{2} \mathrm{O}\right)_{6}\right]^{3+}$ complexes. At $500{ }^{\circ} \mathrm{C}$ iron ions are in the pores in tetrahedral sites as $\left[\mathrm{Fe}(\mathrm{OH})_{4}\right]^{3+}(\mathrm{IS}=0.22 \pm 0.03$; $I(\%)=15.51)$. Most of water has gone out between 120 and $500{ }^{\circ} \mathrm{C}$ (Fig. 1). The isomer shift, quadropole splitting and the relative area values, for $\mathrm{Fe}^{3+}$, at 500 and $1000{ }^{\circ} \mathrm{C}$ (Table 1) suggest that iron ions are not in a similar place. From $1000{ }^{\circ} \mathrm{C}$ the glass structure is densified, as observed by SEM [8], and $\mathrm{Fe}^{3+}$ ions are incorporated in the silicate structure as a network former. The quadrapole splitting has a value higher at $1000{ }^{\circ} \mathrm{C}$ than at $500{ }^{\circ} \mathrm{C}$ because the tetrahedral site is less 
Table 1

Mössbauer parameters fitted to the spectra taken at $300 \mathrm{~K}$ of the $10 \mathrm{Fe}_{2} \mathrm{O}_{3} \cdot 10 \mathrm{Al}_{2} \mathrm{O}_{3} \cdot 80 \mathrm{SiO}_{2} \mathrm{sample}$

\begin{tabular}{|c|c|c|c|c|c|}
\hline & IS $(\mathrm{mm} / \mathrm{s})$ & $\mathrm{QS}(\mathrm{mm} / \mathrm{s})$ & $\Gamma(\mathrm{mm} / \mathrm{s})$ & $H(\mathrm{~T})$ & $I(\%)$ \\
\hline $\begin{array}{l}250{ }^{\circ} \mathrm{C} \\
\mathrm{Fe}^{3+} \\
\text { Goethite }(\alpha-\mathrm{FeOOH}) \\
\text { Hematite }\left(\alpha-\mathrm{Fe}_{2} \mathrm{O}_{3}\right)\end{array}$ & $\begin{array}{l}0.36 \pm 0.01 \\
0.38 \pm 0.02 \\
0.37 \pm 0.01\end{array}$ & $\begin{array}{r}0.56 \pm 0.05 \\
-0.17 \pm 0.03 \\
-0.22 \pm 0.02\end{array}$ & $\begin{array}{l}1.01 \pm 0.05 \\
1.49 \pm 0.06 \\
0.60 \pm 0.04\end{array}$ & $\begin{array}{l}- \\
42.73 \pm 0.19 \\
47.91 \pm 0.08\end{array}$ & $\begin{array}{l}15.01 \\
55.24 \\
29.75\end{array}$ \\
\hline $\begin{array}{l}500{ }^{\circ} \mathrm{C} \\
\mathrm{Fe}^{3+} \\
\text { Goethite }(\alpha-\mathrm{FeOOH}) \\
\text { Hematite }\left(\alpha-\mathrm{Fe}_{2} \mathrm{O}_{3}\right)\end{array}$ & $\begin{array}{l}0.23 \pm 0.01 \\
0.35 \pm 0.01 \\
0.35 \pm 0.01\end{array}$ & $\begin{array}{r}0.28 \pm 0.08 \\
-0.15 \pm 0.01 \\
-0.23 \pm 0.01\end{array}$ & $\begin{array}{l}0.80 \pm 0.01 \\
1.65 \pm 0.15 \\
0.67 \pm 0.02\end{array}$ & $\begin{array}{l}- \\
38.42 \pm 0.06 \\
49.55 \pm 0.04\end{array}$ & $\begin{array}{l}12.86 \\
15.06 \\
72.08\end{array}$ \\
\hline $\begin{array}{l}1000{ }^{\circ} \mathrm{C} \\
\mathrm{Fe}^{3+} \\
\text { Hematite }\left(\alpha-\mathrm{Fe}_{2} \mathrm{O}_{3}\right)\end{array}$ & $\begin{array}{l}0.31 \pm 0.02 \\
0.36 \pm 0.01\end{array}$ & $\begin{array}{r}0.45 \pm 0.05 \\
-0.21 \pm 0.01\end{array}$ & $\begin{array}{l}0.80 \pm 0.01 \\
0.57 \pm 0.01\end{array}$ & $\begin{array}{l}- \\
49.36 \pm 0.01\end{array}$ & $\begin{array}{r}5.50 \\
94.50\end{array}$ \\
\hline $\begin{array}{l}200{ }^{\circ} \mathrm{C} \\
\mathrm{Fe}^{3+} \\
\text { Hematite }\left(\alpha-\mathrm{Fe}_{2} \mathrm{O}_{3}\right)\end{array}$ & $\begin{array}{l}0.30 \pm 0.02 \\
0.36 \pm 0.01\end{array}$ & $\begin{array}{r}0.95 \pm 0.04 \\
-0.22 \pm 0.01\end{array}$ & $\begin{array}{l}0.60 \pm 0.01 \\
0.38 \pm 0.01\end{array}$ & $\begin{array}{l}- \\
50.01 \pm 0.07\end{array}$ & $\begin{array}{r}8.72 \\
91.28\end{array}$ \\
\hline $\begin{array}{l}1300{ }^{\circ} \mathrm{C} \\
\mathrm{Fe}^{3+} \\
\text { Hematite }\left(\alpha-\mathrm{Fe}_{2} \mathrm{O}_{3}\right)\end{array}$ & $\begin{array}{l}0.29 \pm 0.01 \\
0.36 \pm 0.01\end{array}$ & $\begin{array}{r}0.99 \pm 0.02 \\
-0.21 \pm 0.01\end{array}$ & $\begin{array}{l}0.49 \pm 0.03 \\
0.40 \pm 0.03\end{array}$ & $\begin{array}{l}- \\
50.25 \pm 0.01\end{array}$ & $\begin{array}{r}7.84 \\
92.16\end{array}$ \\
\hline
\end{tabular}

IS - isomer shift; QS - quadrapole splitting; $\Gamma$ - line width; $H$ - average magnetic hyperfine field; $I$ - relative area.

symmetric when $\mathrm{Fe}^{3+}$ ions are incorporated in the silicate structure. The amount of $\mathrm{Fe}^{3+}$, incorporated as a former, is higher at 1200 and $1300{ }^{\circ} \mathrm{C}$ than at $1000{ }^{\circ} \mathrm{C}$ (see Section 3.2). This indicates the dissolution of hematite particles present in all the samples [8,9]. The shift of the FTIR band at $800 \mathrm{~cm}^{-1}$, to lower wave numbers, at 1200 and $1300{ }^{\circ} \mathrm{C}$ (Fig. 1), confirms the increasing in the incorporation of iron as a network former. The shift is due to the fact that $\mathrm{Fe}-\mathrm{O}$ bonds are more ionic than $\mathrm{Si}-\mathrm{O}$ bond, which gives rise to a reducing in the tensile of the $\mathrm{Si}-\mathrm{O}-\mathrm{Si}$ bonds at the expense of the distortion of $\mathrm{FeO}_{4}$ units [13]. Only a little part of the iron oxide is incorporated in the silicate network the rest is dispersed as hematite (in all the samples) and goethite (250 and $500{ }^{\circ} \mathrm{C}$ ) particles. The sextet present in all the Mössbauer spectra (Fig. 2) are characteristic of the goethite and hematite presence. The average magnetic hyperfine data (Table 1), for hematite, indicates that a small amount of iron was replaced by aluminium in these particles $[20,24]$. As shown by Janot [24] in the $\left(\mathrm{Fe}_{1-x}, \mathrm{Al}_{x}\right)_{2} \mathrm{O}_{3}$ (hematite) particles, the hyperfine field decreases linearly with $x$. For the samples in study the $\mathrm{H}$ and $x$ values are registered in Table 2 . The $x$
Table 2

Average hyperfine field and $x$ values for the $\left(\mathrm{Fe}_{1-x}, \mathrm{Al}_{x}\right)_{2} \mathrm{O}_{3}$ (hematite) particles

\begin{tabular}{cll}
\hline$T\left({ }^{\circ} \mathrm{C}\right)$ & $H(\mathrm{~T})$ & $x^{\mathrm{a}}$ \\
\hline 250 & $47.91 \pm 0.08$ & 0.42 \\
500 & $49.55 \pm 0.04$ & 0.21 \\
1000 & $49.36 \pm 0.01$ & 0.24 \\
1200 & $50.01 \pm 0.01$ & 0.15 \\
1300 & $50.25 \pm 0.01$ & 0.12 \\
\hline
\end{tabular}

${ }^{\text {a }} x$ is obtained using the equation $H=-7.69 x+51.17$ [20].

value is higher at $250{ }^{\circ} \mathrm{C}$. This result can be understood by considering that, as confirmed by SEM and EPR [8,9], between 250 and $1000{ }^{\circ} \mathrm{C}$, iron particles suffer a decrease in dimensions. This indicates dissolution of hematite particles with increasing heat treatment. Nevertheless, there is a corresponding network closing with segregation of iron oxide particles. At $1000{ }^{\circ} \mathrm{C}$ the network closing seems to reach a maximum. For this reason, at $1000{ }^{\circ} \mathrm{C}$, the amount of iron incorporated as tetrahedral $\mathrm{Fe}^{3+}$ is minimum $(I(\%)=5.50-$ Table 1$)$ and that of hematite maximum $(I(\%)=94.50$ - Table 1$)$. The tetrahedral $\mathrm{Fe}^{3+}$ inserted in the glass matrix increases at 1200 and $1300{ }^{\circ} \mathrm{C}$, due to the dissolution of hematite particles (Table 1). 
In all the samples, iron is incorporated as $\mathrm{Fe}^{3+}$ because the introduction of $\mathrm{Fe}$ and $\mathrm{Al}$ as nitrates seems to prevent $\mathrm{Fe} 3+$ to $\mathrm{Fe}^{2+}$ reduction between 120 and $1300{ }^{\circ} \mathrm{C}$.

\section{Conclusions}

This study shows that:

(a) The glass network formed by the sol-gel method is porous between 120 and $500{ }^{\circ} \mathrm{C}$. At $800{ }^{\circ} \mathrm{C}$ the presence of pores was not detected.

(b) At $250{ }^{\circ} \mathrm{C}, \mathrm{Fe}^{3+}$ ions are in the pores as octahedral $\left[\mathrm{Fe}\left(\mathrm{H}_{2} \mathrm{O}\right)_{x}(\mathrm{OH})_{6-x}\right]^{3+}$ and/or $[\mathrm{Fe}$ $\left.\left(\mathrm{H}_{2} \mathrm{O}\right)_{6}\right]^{3+}$ complexes.

(c) At $500{ }^{\circ} \mathrm{C}, \mathrm{Fe}^{3+}$ ions are in the pores as tetrahedral $\left[\mathrm{Fe}(\mathrm{OH})_{4}\right]^{3+}$ complexes.

(d) From $1000{ }^{\circ} \mathrm{C}, \mathrm{Fe}^{3+}$ ions are incorporated in the silicate network as press formers.

(e) In the 250 and $500{ }^{\circ} \mathrm{C}$ samples, goethite particles are detected.

(f) In all the samples, hematite particles are present. However, a small amount of iron is replaced by aluminium in these particles.

\section{Acknowledgements}

The authors thanks the FCT (Portuguese Foundation for Science and Technology) and Research Institut of Aveiro (Proj. 3401) for financial support.

\section{References}

[1] C.R. Kurkijian, J. Non-Cryst. Solids 3 (1970) 157.

[2] K.E. Fox, T. Furukawa, W.B. White, Phys. Chem. Glasses 23 (1982) 169.

[3] A. Montenero, M. Friggeri, D.C. Giori, N. Belkhiria, L.D. Pye, J. Non-Cryst. Solids 84 (1986) 45.

[4] B.O. Mysen, D. Virgo, Am. Mineral. 74 (1989) 58.

[5] D. Virgo, B.O. Mysen, Phys. Chem. Miner. 12 (1985) 65.

[6] M.F. Taragin, J.C. Eisenstein, J. Non-Cryst. Solids 3 (1970) 311.

[7] Ch. Labor, P. Gielen, J. Non-Cryst. Solids 13 (1973) 107.

[8] M.G. Ferreira da Silva, M.A. Valente, J. Non-Cryst. Solids 232-234 (1998) 409.

[9] M.G. Ferreira da Silva, M.A. Valente, J. Sol-Gel Sci. Technol. 17 (2000) 47.

[10] P. Manier, A. Narotsky, A.M. Rabinovich, D.L. Wood, N.A. Kopylov, Mater. Res. Soc. Symp. Proc. 121 (1988) 323.

[11] G. Zaho, N. Tohge, Mater. Res. Bull. 33 (1998) 21.

[12] K. Kato, J. Mater. Sci. 26 (1991) 6777.

[13] Z. Zhang, Phys. Chem. Glasses 34 (1993) 95.

[14] N.P. Bansal, J. Am. Ceram. Soc. 71 (1988) 666.

[15] M. Sales, J. Alarcón, J. European Ceram. Soc. 16 (1996) 781.

[16] J. Zarzycki, Glasses and Vitreous State, Cambridge University, Cambridge, 1991.

[17] J.W. Park, H. Chen, J. Non-Cryst. Solids 40 (1980) 515.

[18] J. Wong, C.A. Angell, Glass Structure by Spectroscopy, Marcel Dekker, New York, 1976.

[19] M.D. Dyer, Am. Mineral. 70 (1985) 304.

[20] N.N. Greenwood, T.C. Gibb, Mössbauer Spectroscopy, Chapman and Hall, New York, 1971.

[21] M.G. Ferreira da Silva, M. Garcia, J.R. Gancedo, J.M.F. Navarro, in: Proceedings of the First International Workshop on Non-Crystalline Solids, World Scientific, Singapore, 1986, p. 441.

[22] M.G. Ferreira da Silva, J.M.F. Navarro, J. Sol-Gel Sci. Technol. 6 (1996) 169.

[23] B.E. Yoldas, J. Mater. Sci. 14 (1979) 1843.

[24] C. Janot, L'Effect Mössbauer et Ses Applications, Masson, Paris, 1972. 